\title{
Zenaga Language
}

National Cancer Institute

\section{Source}

National Cancer Institute. Zenaga Language. NCI Thesaurus. Code C154206.

An Afro-Asiatic Berber language spoken from the town of Mederdra in southwestern Mauritania to the Atlantic coast and in Senegal. 